\title{
Genome-Assisted Development of a Diagnostic Protocol for Distinguishing High Virulence Pseudomonas syringae pv. tomato Strains
}

Lisa A. Jones, Department of Plant Pathology and Plant-Microbe Biology, Cornell University, Geneva, NY 14456; Surya Saha, Department of Plant Pathology and Plant-Microbe Biology, Cornell University, Ithaca, NY 14850; and Boyce Thompson Institute for Plant Research, Ithaca, NY 14853; Alan Collmer, Department of Plant Pathology and Plant-Microbe Biology, Cornell University, Ithaca, NY 14850; Christine D. Smart, Department of Plant Pathology and Plant-Microbe Biology, Cornell University, Geneva, NY 14456; and Magdalen Lindeberg, Department of Plant Pathology and Plant-Microbe Biology, Cornell University, Ithaca, NY 14850.

\begin{abstract}
Jones, L. A., Saha, S., Collmer, A., Smart, C. D., and Lindeberg, M. 2015. Genome-assisted development of a diagnostic protocol for distinguishing high virulence Pseudomonas syringae pv. tomato strains. Plant Dis. 99:527-534.

A severe outbreak of bacterial speck of tomato, caused by Pseudomonas syringae pv. tomato, occurred in central New York in 2009. Isolate 09150, collected from this outbreak and subsequently named NYS-T1, was found to be highly virulent on tomato. To better understand the relationship of 09150 to other $P$. syringae strains and develop a diagnostic assay for aggressive strains of this pathogen, the 09150 genome was sequenced. Genome comparison revealed it to be highly similar to a previously sequenced isolate, T1. Genetic factors linked to host interaction including type III effectors, toxin biosynthetic genes, and elicitors of host innate immunity were identified. Type III effector repertoires were compared with other strains in the high virulence T1-like subgroup and

lower virulence DC3000/P. syringae pv. maculicola subgroup within $P$. syringae phylogenetic Group I. Primers for conventional PCR were developed using sequences for avrA, hop $W$, conserved in the former subgroup and hopN, present in the latter. These were tested on isolates in the two subgroups, other pseudomonads, and other bacterial pathogens of tomato. Primers developed for avaA and hop $W$ were diagnostic for more virulent strains of $P$. syringae pv. tomato while primers for hopN were diagnostic for $P$. syringae pv. tomato DC3000 and related $P$. syringe pv. maculicola strains. Primers designed against hopR distinguished both of these $P$. syringae subgroups from other $P$. syringae strains.
\end{abstract}

Pseudomonas syringae pv. tomato is the causal agent of bacterial speck disease of tomato (Solanum lycopersicum L.) and affects tomato production worldwide (28). Bacterial speck can be severe and lead to substantial economic losses $(29,48)$. The pathogen is disseminated through infested seed and can survive in infected debris and epiphytically on weeds (35). For tomatoes grown commercially in New York, new strains typically arrive on infected seed or transplants. Virulence can vary widely among $P$. syringae pv. tomato strains and several other bacterial pathogens of tomato cause symptoms similar to those of $P$. syringae pv. tomato, complicating management of bacterial speck (30). Diagnostics specific to the more virulent $P$. syringae pv. tomato could enhance disease management practices.

During the late summer of 2009, a highly virulent strain of $P$. syringae pv. tomato (09150) was isolated from an Ontario County, NY tomato field. The severity of this isolate, subsequently named NYS-T1, resulted in total loss of yield from a 5-acre field, prompting interest in development of diagnostic tools that could be used to distinguish highly virulent $P$. syringae pv. tomato strains from milder $P$. syringae strains as well as from other bacterial pathogens causing speck-like symptoms. This latter group includes Xanthomomas spp. (Xanthomomas vesicatoria, X. euvesicatora, X. gardneri, and $X$. perforans) causing bacterial spot of tomato and Clavibacter michiganensis subsp. michiganensis, the causal agent of bacterial wilt and canker of tomato $(19,22,24)$. P. viridiflava, the causal agent of bacterial leaf blight and stem pith necrosis of tomato, can also cause speck-like symptoms $(23,34)$ and was found in 2010 on the same farm from which $P$. syringae pv. tomato 09150 had been isolated.

DNA-based detection of $P$. syringae pv. tomato strains from infected tomato has typically been conducted using sequences of

Corresponding author: M. Lindeberg, E-mail: ml16@cornell.edu

Accepted for publication 4 November 2014.

http://dx.doi.org/10.1094/PDIS-08-14-0833-RE

(C) 2015 The American Phytopathological Society $h r p Z$ and other genes in the $h r p / h r c$ gene cluster that do not distinguish among strains having different virulence levels $(20,21,49)$. Genes involved in biosynthesis of the phytotoxin coronatine have also been used for DNA-based detection $(16,36)$, although coronatine biosynthesis is not strongly correlated with either strain phylogeny or the degree of virulence (5). A detection protocol capable of distinguishing more virulent $P$. syringae pv. tomato strains from both less virulent strains and other bacterial pathogens associated with tomato would aid growers in making pest management decisions when faced with an early stage infection in the field.

Several $P$. syringae strains, most notably $P$. syringae pv. tomato DC3000, have been developed as model systems for genomicsenabled characterization of bacterium-host interactions. Consequently, there is a wealth of sequence data available for use in development of DNA-based diagnostic tools. Information on complete and draft genomes of $P$. syringae isolates and related Pseudomonas species can be found at the Pseudomonas-Plant Interaction Resource (www. pseudomonas-syringae.org) and at www.pseudomonas.com with an extensive catalog of sequences for conducting MLST analysis available at the Plant Associated and Environmental Microbes Database (www.PAMDB.org). P. syringae strains isolated from agricultural settings fall into three major phylogenetic groups with pathovars tomato, maculicola, and actinidae assigned to "Group I" $(4,40)$. Included in Group II are the $P$. syringae pathovars syringae and pisi and Group III pathovar examples are glycinea, phaseolicola, and aesculi. Multilocus sequence typing of Group I strains further reveals that more virulent isolates of $P$. syringae pv. tomato, exemplified by strain T1, cluster together $(10,47)$. In contrast, strain DC3000 belongs to a different subgroup, which includes strains more closely related to $P$. syringae pv. maculicola. The two subgroups are referred to here as "T1-like" and "DC3000/P syringae pv. maculicola." Strains in the latter subgroup generally have a broader host range extending to Arabidopsis thaliana (L.), cauliflower (Brassica oleracea L. var. botrytis), and other brassicas, while those in the T1-like subgroup cause disease on tomato but not cauliflower or Arabidopsis $(15,46,47)$. Analysis of strains collected over a 70 -year time period indicates that in Europe and North America, the T1-like subgroup 
has been isolated with increasing frequency relative to DC3000/P. syringae pv. maculicola strains (10).

To better understand how the field isolate 09150 corresponds to the two subgroups and to identify sequence signatures that reliably distinguish high and low virulence strains, isolate 09150 was sequenced and the repertoire of predicted virulence determinants compared with those of related $P$. syringae strains. Virulence factors receiving particular attention included type III effector (T3E) repertoires, phytotoxins, and gene products linked to induction of innate immunity in the host. Here we report these virulence factors and on a PCR-based subspecific diagnostic assay developed from genomic comparison of $P$. syringae pv. tomato strains with varying levels of virulence.

\section{Materials and Methods}

Bacterial cultures and DNA extraction. Bacterial isolates used in this study were obtained from frozen cultures stored at $-80^{\circ} \mathrm{C}$ from the culture collections in the laboratories of C. Smart and A. Collmer at Cornell University (Table 1). Isolates of Pseudomonas spp., $X$. perforans, and C. michiganensis were maintained on King's B agar, yeast dextrose carbonate agar, and D2ANX agar, respectively, at $28^{\circ} \mathrm{C}$ $(13,27,46)$. For DNA extraction, overnight cultures were grown in Luria-Bertani (LB) broth at $28^{\circ} \mathrm{C}$ on a rotary shaker at $200 \mathrm{rpm}(6)$. DNA extraction was performed according to the protocol by Chen and Kuo (11). For DNA extraction of $P$. syringae pv. tomato from infected and healthy tomato tissue, the protocol from Keb-Llanes et al. (25) was used with modifications (polyvinylpyrrolidone and $\beta$-mercaptoethanol were omitted from extraction buffer A).

Genomic sequencing of $\boldsymbol{P}$. syringae pv. tomato 09150 . Genomic DNA from $P$. syringae pv. tomato 09150 was extracted according to the protocol from Chen and Kuo (11) with modification (an extraction with an equal volume phenol/chloroform/isoamyl alcohol [25:24:1] was performed with the supernatant from cell lysis after separation from cellular debris) and was sequenced using Illumina HiSeq (Illumina, Inc., San Diego, CA) at the Cornell University's Genomics Core Facility in Ithaca, NY. Initial coverage of 2,434x was reduced to $2,013 \times$ after quality trimming and error correction with Quake (version 0.2.2) (26). De novo assembly was conducted using Velvet (version 1.1.04) (50) and mapping assembly against the $P$. syringae pv. tomato T1 reference genome with MIRA (version 3.4.0 prod_linux-gnu_x86_64_static) (12). The assemblies were manually analyzed using MAUVE (17). Overlapping contigs were merged using Minimus2 from the AMOS package (version 3.0.0., www.sourgeforce.net). A final round of scaffolding was performed using SSPACE (version 1.1) with default parameters (8). Genome annotation of the resulting 188 contigs was conducted with RAST (3) and HrpL binding sites were predicted with Pred_cutoff (38). To determine the phylogenetic placement of strain 09150, sequences corresponding to the 9-gene MLST schema described by Almeida et al. (1) were identified from the 09150 genome assembly. Sequences used for the MLST analyses were obtained from the Plant Associated and Environmental Database (www.PAMDB.org) for $P$. syringae pv. tomato isolates Max13, kuzzen 40, T1, NCPPB 1108, JL1065, Pan 126, DC3000, ICMP3443; $P$. syringae pv. maculicola isolates M3 and M6; and $P$. syringae $\mathrm{pv}$. syringae $\mathrm{B} 728 \mathrm{a}$. Sequences for $P$. viridiflava UASWS0039, P. fluorescens NCIMB 11764, $P$. syringae pv. glycinea $\mathrm{B} 076$, and $P$. syringae aesculi 2250 were obtained from the National Center for Biotechnology (www.ncbi.nlm.nih.gov). A phylogenetic tree was produced using the neighbor-joining method in MEGA6 $(39,41)$. The evolutionary distances were computed using the Maximum Composite Likelihood method (42). The GenBank accession number for the NYS-T1 sequence data are JRRA00000000. Additional genome resources for NYS-T1 can be found on the Pseudomonas-Plant Interaction web site at http:// pseudomonas-syringae.org/Pto-NYS-T1_Genome_Resources.html.

Primer design. Sequences for T3E genes, avrA, hopWl, hopNl, and hopR1, were aligned using MEGA6 (Table 3). Primer sequences were designed for each gene using a visual assessment of aligned sequences combined with Integrated DNA technologies (IDT, Coralville, IA) OligoAnalyzer tool (https://www.idtdna.com/analyzer/ Applications/OligoAnalyzer/).

Table 1. Bacterial isolates used in this study

\begin{tabular}{|c|c|c|c|c|c|c|}
\hline Species & Isolate & Host of isolation & Origin & Year & Source & Reference \\
\hline \multirow[t]{14}{*}{ Pseudomonas syringae pv. tomato } & $0578^{z}$ & Solanum lycopersicum & NY, USA & 2005 & C. Smart & This study \\
\hline & $0761^{z}$ & S. lycopersicum & NY, USA & 2007 & C. Smart & This study \\
\hline & $09084^{z}$ & S. lycopersicum & NY, USA & 2009 & C. Smart & This study \\
\hline & $09150^{\mathrm{z}}$ & S. lycopersicum & NY, USA & 2009 & C. Smart & This study \\
\hline & $12042^{\mathrm{z}}$ & S. lycopersicum & NY, USA & 2012 & C. Smart & This study \\
\hline & 13093 & S. lycopersicum & NY, USA & 2013 & C. Smart & This study \\
\hline & 13110 & S. lycopersicum & NY, USA & 2013 & C. Smart & This study \\
\hline & $\mathrm{K} 40^{\mathrm{z}}$ & S. lycopersicum & USA & 2005 & A. Collmer & 10 \\
\hline & $\mathrm{A} 9^{\mathrm{z}}$ & S. lycopersicum & USA & 1996 & C. Smart & 21 \\
\hline & JL1065z & S. lycopersicum & CA, USA & & A. Collmer & 44 \\
\hline & NCPPB 1108 & S. lycopersicum & Jersey, UK & 1961 & A. Collmer & \\
\hline & $\operatorname{Max} 13$ & S. lycopersicum & France & & A. Collmer & 49 \\
\hline & $\mathrm{T} 1$ & S. lycopersicum & Canada & & A. Collmer & 37 \\
\hline & $\mathrm{DC} 3000^{\mathrm{z}}$ & S. lycopersicum & Geurnsey, UK & 1961 & A. Collmer & 14 \\
\hline P. syringae pv. antirrhini & Pat $126^{\mathrm{z}}$ & Antirrhinum majus & & 1965 & A. Collmer & 47 \\
\hline \multirow[t]{2}{*}{ P. syringae pv. maculicola } & $\mathrm{M}^{\mathrm{z}}$ & Brassica olerancea var. botrytis & USA & 1937 & A. Collmer & 18 \\
\hline & $M 6^{z}$ & B. olerancea var. botrytis & UK & 1965 & A. Collmer & 18 \\
\hline P. syringae pv. syringae & $\mathrm{B} 728^{\mathrm{z}}$ & Phaseolus vulgaris & WI, USA & & C. Smart & 33 \\
\hline$P$. viridiflava & $10078^{z}$ & S. lycopersicum & NY, USA & 2010 & C. Smart & This study \\
\hline P. fulva & $0430^{\mathrm{z}}$ & S. lycopersicum & NY, USA & 2004 & C. Smart & This study \\
\hline P. fluorescens & $09110^{z}$ & S. lycopersicum & NY, USA & 2009 & C. Smart & This study \\
\hline P. putida & $09112^{z}$ & S. lycopersicum & NY, USA & 2009 & C. Smart & This study \\
\hline Xanthomonas perforans & 13091 & S. lycopersicum & NY, USA & 2013 & C. Smart & This study \\
\hline \multirow{4}{*}{$\begin{array}{l}\text { Clavibacter michiganensis subsp. } \\
\text { michiganensis }\end{array}$} & 13048 & S. lycopersicum & NY, USA & 2013 & C. Smart & This study \\
\hline & 13085 & S. lycopersicum & NY, USA & 2013 & C. Smart & This study \\
\hline & 13117 & S. lycopersicum & NY, USA & 2013 & C. Smart & This study \\
\hline & 13129 & S. lycopersicum & NY, USA & 2013 & C. Smart & This study \\
\hline
\end{tabular}

${ }^{\mathrm{z}}$ Isolates used in virulence assay. All isolates were used in primer development. 
Primer testing. Each primer combination (Table 4) was tested using the Bio-Rad C1000 Touch Thermal Cycler (Bio-Rad, Hercules, CA). A temperature gradient of 56 to $65^{\circ} \mathrm{C}$ was used to determine the optimum annealing temperature for each primer pair. Twentyfive microliter reactions contained $1 \times$ EmeraldAmp PCR MasterMix (Clonetch, Mountain View, CA), 10 pmol forward primer, 10 pmol reverse primer, and 10 ng template DNA. Multiplex PCR was performed with primers for avrA (215f and 1321r) and hopRl (427f and 1129r) with the same reaction mixture as above except that 7.5 pmol of each primer was used. PCR conditions were as follows: initial denaturation of $94^{\circ} \mathrm{C}$ for $4 \mathrm{~min}$, followed by 35 cycles at $94^{\circ} \mathrm{C}$ for $45 \mathrm{~s}, 56$ to $65^{\circ} \mathrm{C}$ for 30 $\mathrm{s}, 72^{\circ} \mathrm{C}$ for $45 \mathrm{~s}$, and a final extension step of $72^{\circ} \mathrm{C}$ for $5 \mathrm{~min}$. PCR products were electrophoresed for $60 \mathrm{~min}$ at $100 \mathrm{~V}$ on a $1 \%$

Table 2. Predicted virulence factors for P. syringae pv. tomato DC3000, T1, and NYS-T1 from genomic data. X's indicate the presence of full length reading frames

\begin{tabular}{|c|c|c|c|}
\hline & DC3000 & $\mathbf{T 1}$ & NYS-T1 \\
\hline \multicolumn{4}{|l|}{ Type III effectors } \\
\hline AvrE1 & $X$ & $\mathrm{X}$ & $\mathrm{X}$ \\
\hline HopC1 & $\mathrm{X}$ & $\mathrm{X}$ & $\mathrm{X}$ \\
\hline HорH1 & $\mathrm{X}$ & $\mathrm{X}$ & $\mathrm{X}$ \\
\hline HopI1 & $\mathrm{X}$ & $\mathrm{X}$ & $\mathrm{X}$ \\
\hline HopR1 & $\mathrm{X}$ & $\mathrm{X}$ & $\mathrm{X}$ \\
\hline HopO1-2 & $\mathrm{X}$ & $\mathrm{X}$ & $\mathrm{X}$ \\
\hline HopS2 & $X$ & $\mathrm{X}$ & $\mathrm{X}$ \\
\hline HopT1-2 & $\mathrm{X}$ & $\mathrm{X}$ & $\mathrm{X}$ \\
\hline HopY1 & $\mathrm{X}$ & $\mathrm{X}$ & $\mathrm{X}$ \\
\hline HopAA1-1 & $X$ & $\mathrm{X}$ & $\mathrm{X}$ \\
\hline HopF2 & $\mathrm{X}$ & $\mathrm{X}$ & $\mathrm{X}$ \\
\hline HopD1 & $\mathrm{X}$ & $\mathrm{X}$ & $\mathrm{X}$ \\
\hline HopQ1 & $\mathrm{X}$ & $\mathrm{X}$ & $\mathrm{X}$ \\
\hline HopO1-1 & $\mathrm{X}$ & $\mathrm{X}$ & $\mathrm{X}$ \\
\hline HopT1-1 & $\mathrm{X}$ & $\mathrm{X}$ & $\mathrm{X}$ \\
\hline HopAF1 & $\mathrm{X}$ & $\mathrm{X}$ & $\mathrm{X}$ \\
\hline HopW1 & & $\mathrm{X}$ & $\mathrm{X}$ \\
\hline AvrA & & $\mathrm{X}$ & $\mathrm{X}$ \\
\hline HopAS1 & & $\mathrm{X}$ & $X$ \\
\hline HopS1 & & $\mathrm{X}$ & $\mathrm{X}$ \\
\hline HopAE1 & & $\mathrm{X}$ & $\mathrm{X}$ \\
\hline HopAG1 & & $\mathrm{X}$ & $\mathrm{X}$ \\
\hline HopAH1 & & $\mathrm{X}$ & $\mathrm{X}$ \\
\hline HopAI1 & & $\mathrm{X}$ & $\mathrm{X}$ \\
\hline AvrRpt2 & & $\mathrm{X}$ & $\mathrm{X}$ \\
\hline AvrD1 & & $\mathrm{X}$ & $\mathrm{X}$ \\
\hline HopAB2(AvrPtoB) & $\mathrm{X}$ & & \\
\hline HopA1 & $\mathrm{X}$ & & \\
\hline HopB1 & $\mathrm{X}$ & & \\
\hline HopM1 & $\mathrm{X}$ & & \\
\hline HopN1 & $\mathrm{X}$ & & \\
\hline HopE1 & $\mathrm{X}$ & & \\
\hline HopG1 & $\mathrm{X}$ & & \\
\hline HopV1 & $\mathrm{X}$ & & \\
\hline HopAA1-2 & $\mathrm{X}$ & & \\
\hline HopAD1 & $X$ & & \\
\hline HopAM1 (2 copies) & $\mathrm{X}$ & & \\
\hline HopAO1 & $\mathrm{X}$ & & \\
\hline HopAQ1 & $\mathrm{X}$ & & \\
\hline AvrPto1 & $\mathrm{X}$ & & \\
\hline HopAO-like candidate & & & $\mathrm{X}$ \\
\hline \multicolumn{4}{|l|}{ Hrp regulon } \\
\hline PSPTO_0834-0836 & $X$ & & \\
\hline PSPTO_4733 & $\mathrm{X}$ & & \\
\hline \multicolumn{4}{|l|}{ Toxins } \\
\hline coronatine & $X$ & & $X$ \\
\hline \multicolumn{4}{|l|}{ PAMP elicitation } \\
\hline flgII-28 epitope of FliC & $\mathrm{X}$ & $\mathrm{X}$ & \\
\hline \multicolumn{4}{|l|}{ Other } \\
\hline type II restriction & & & $\mathrm{X}$ \\
\hline
\end{tabular}

agarose gel stained with ethidium bromide. Primers were tested with DNA from all isolates listed in Table 1, infected tomato leaf tissues ( $P$. syringae pv. tomato 09150 and DC3000), infected tomato fruit ( $P$. syringae pv. tomato 13093 and 13110), and healthy tomato leaves. Infected and healthy tomato leaf tissues were collected from cultivar Mountain Fresh Plus. Infected tomato fruit tissues were obtained from field samples collected from unknown cultivars.

Virulence assay. Five-week-old tomato plants ('Mountain Fresh Plus') were inoculated with pseudomonads (Table 1) from overnight bacterial cultures grown in LB broth at $28^{\circ} \mathrm{C}$ on rotary shaker $(200 \mathrm{rpm})$. Inoculum was prepared by adjusting bacterial concentration to an OD600 of 0.05 (approximately $10^{7} \mathrm{CFU} / \mathrm{ml}$ ) in $50 \mathrm{ml}$ of $1 \times$ phosphate buffered saline $(137 \mathrm{mM} \mathrm{NaCl}, 2.7 \mathrm{mM}$ $\mathrm{KCl}, 10 \mathrm{mM} \mathrm{Na}_{2} \mathrm{HPO}_{4}, 2 \mathrm{mM} \mathrm{KH} \mathrm{PO}_{4}$ ) containing $0.25 \%$ Tween. Plants were dip-inoculated and kept in a greenhouse at $24^{\circ} \mathrm{C}$ (daytime) and $20^{\circ} \mathrm{C}$ (nighttime) with $14 \mathrm{~h}$ light per day. Two plants per isolate were inoculated one repetition and four plants per isolate were inoculated for a second repetition. Plants were rated for disease by counting the number of specks per leaflet on the first two true leaves, starting 6 days post inoculation when specks were first visible and continuing every 2 days for a total of four ratings. Analysis of variance and Tukey's honestly significant differences were calculated from data from the fourth rating (12 days postinoculation) using JMP Pro 10 (SAS Institute, Cary, NC) to determine significant differences $(\alpha=0.05)$ between mean specks per leaflet for each isolate. No significant differences were found between repetitions and data from both repetitions were combined for analysis using a total of six plants per isolate.

\section{Results}

Genome annotation reveals predicted virulence determinants encoded by $P$. syringae pv. tomato NYS-T1. The overall genome size of $6.26 \mathrm{Mb}$ for $P$. syringae pv. tomato NYS-T1 falls within the size range observed for previously sequenced $P$. syringae strains. Multilocus sequence typing of NYS-T1 with the schema described by Yan et al. (47) phylogenetically places it with Group I strains, clustering most closely with four strains in the T1-like subgroup (Fig. 1). To determine whether NYS-T1 encodes a novel combination of virulence associated genes and to facilitate broader comparison of virulence gene repertoires among $P$. syringae strains pathogenic on tomato, candidate virulence genes were identified through sequence comparison and de novo identification of regulatory motifs. Of particular interest were genes linked to phytotoxin biosynthesis, genes encoding Type III effectors (T3Es), and variations in the predicted protein sequences of the conserved pathogen associated molecular patterns (PAMPS) that

Table 3. Sequences from $P$. syringae pv. tomato isolates used for primer design

\begin{tabular}{lll}
\hline Gene & \multicolumn{1}{c}{ Strain } & \multicolumn{1}{c}{ Accession } \\
\hline avrA & NCPPB1108 & ADGA01000238.1 \\
& T1 & ABSM01000053.1 \\
& K40 & ADFY01000462.1 \\
& Max13 & ADFZ01000171.1 \\
& 09150 & this study \\
hopW1 & NCPPB1108 & ADGA01000243.1 \\
& T1 & ABSM01000048.1 \\
& K40 & ADFY01000403.1 \\
& Max13 & ADFZ01000107.1 \\
& 09150 & this study \\
hopN1 & DC3000 & AE016853.1 \\
hopR1 & NCPPB1108 & ADGA01000036.1 \\
& T1 & ABSM01000021.2 \\
& K40 & ADFY01000071.1 \\
& Max13 & ADFZ01000207.1 \\
& 09150 & this study \\
& DC30000 & AE016853.1 \\
\hline
\end{tabular}


trigger host immunity. The T3E repertoires of T1 and NYS-T1 appear to be identical (with a possible exception discussed below), consistent with previous observations of high overall genome conservation among T1-like strains (10). Predicted HrpL regulated genes that are not T3Es are similarly conserved between T1 and NYS-T1, with both strains lacking genes corresponding to PSPTO_4733 and PSPTO_0834-0836 in the non-T3E HrpL regulon of DC3000.
Four differences between strains T1 and NYS-T1 were identified with likely or potential impact on host interaction. Chief among these is the presence of biosynthetic genes for the phytotoxin coronatine in the NYS-T1 genome. Another feature with an experimentally confirmed role in virulence is the presence of a sequence variation in the flgII-28 epitope of NYS-T1 FliC protein, linked to reduced induction of PAMP-triggered immunity in tomato (10).

Table 4. Primers designed for $P$. syringae pv. tomato type III effectors

\begin{tabular}{|c|c|c|c|}
\hline Gene & Primer name and position $^{\mathrm{z}}$ & Sequence & Annealing temp ${ }^{\circ} \mathrm{C}$ \\
\hline \multirow[t]{4}{*}{$a v r A$} & $547 \mathrm{f}$ & 5'-CGATCTCTGTCGAACAATGC-3' & 65 \\
\hline & $215 f$ & 5'-CGCATGTTCAGCATTGTCAT-3' & 65 \\
\hline & $1321 \mathrm{r}$ & 5'-GAAGACCTTGGTTCTTTCGG-3' & 65 \\
\hline & $1219 r$ & 5'-TTGCCTGGTCGATTGTCAAC-3' & 65 \\
\hline \multirow[t]{4}{*}{ hopW1 } & $173 \mathrm{f}$ & 5'-AGGACTTCACAAGCCTTCTG-3' & 65 \\
\hline & $313 \mathrm{f}$ & 5'-GAACAGCAGACACTCAAAGG-3' & 56 \\
\hline & $1099 \mathrm{r}$ & 5'-CCTGTGTCCAATTTGTCCTC-3' & 65 \\
\hline & $1327 \mathrm{r}$ & 5'-CGTCTACGACCTTACCATCG-3' & 56 \\
\hline \multirow[t]{4}{*}{ hopN1 } & 91f & 5'-AATGGAAGCGAGTGTCTGC-3' & 58 \\
\hline & $142 \mathrm{f}$ & 5'-TCTTCACACAGATCGAAAGGC-3' & 58 \\
\hline & $771 \mathrm{r}$ & 5'-CGATAGAGACCATCAGATCCG-3' & 58 \\
\hline & $816 \mathrm{r}$ & 5'-GATTCTGGTCTTGATGTATTGCG-3' & 58 \\
\hline \multirow[t]{4}{*}{ hopRl } & $427 f$ & 5'-GAGATGGAACATGGCATCAG-3' & 65 \\
\hline & $705 f$ & 5'-GATGGTGGAGTCTATCTGC-3' & 65 \\
\hline & $1129 \mathrm{r}$ & 5'-AGGTGAACAGTGTCGTCTC-3' & 65 \\
\hline & $1299 \mathrm{r}$ & 5'-CATGACCATCAAGCTGAACG-3' & 65 \\
\hline
\end{tabular}

${ }^{\mathrm{z}}$ Position corresponds to the $5^{\prime}$ end of the primer in reference to the adenine of the start codon of the corresponding gene, $f$ designates forward primers and $\mathrm{r}$ designates reverse primers.

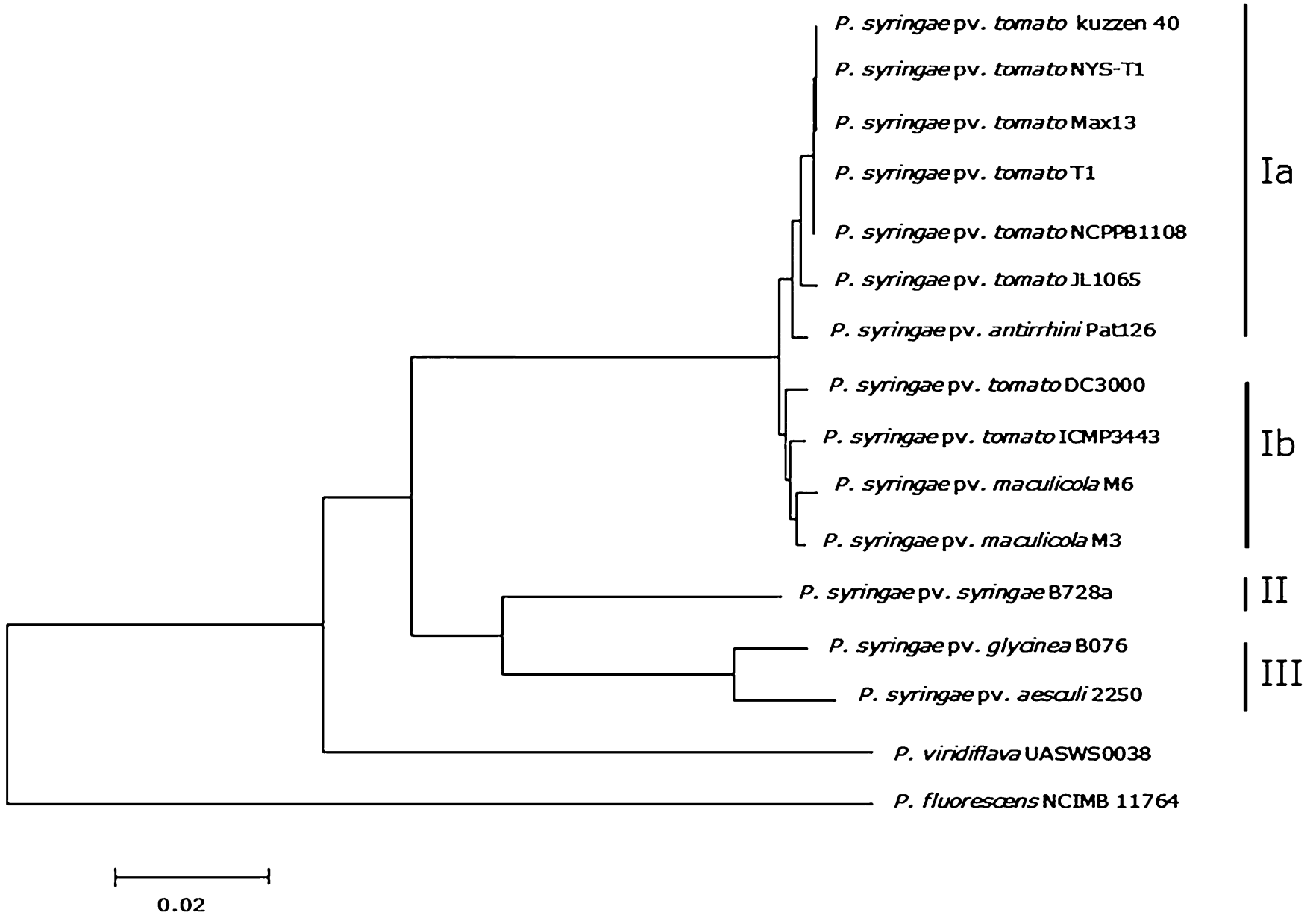

Fig. 1. Evolutionary history of Pseudomonas spp. using the neighbor-joining method. Concatenated sequences and group designations are described by Yan et al. 2008 (47). The tree is drawn to scale, with branch lengths in the same units as those of the evolutionary distances used to infer the phylogenetic tree. 
Additional NYS-T1 features of potential interest include a candidate novel effector having 34\% identity over a 290 amino acid region with the T3E HopAO1, and a type II restriction system that is similarly absent from both T1 and DC3000. Comparison of predicted NYS-T1 virulence factors with those in T1 and DC3000 is shown in Table 2.

Identification of T3E gene profiles conserved within the T1-Like and DC3000/P. syringae pv. maculicola subgroups. To determine the suitability of T3E genes as target loci in the development of DNA-based diagnostic methods, conservation of these genes among sequenced strains in the T1-like subgroup was evaluated. T3E repertoires were predicted from the draft genomes of three T1like strains K40, NCPPB1106, and Max13 collected at different times and in different geographical regions (10). Comparison with T1 and NYS-T1 revealed a high degree of T3E gene conservation, with 19 effectors conserved in all five strains. Among those present in the five T1-like strains but either entirely absent or truncated in the DC3000 genome are hopWl, avrA, and hopAEl. The genes
hopW1 and avrA were selected for primer development, as hopAE1 is present in Pma strains M3 and M6 in the DC3000/P. syringae pv. maculicola subgroup (B. Vinatzer, unpublished data). P. syringae pv. tomato DC3000 has nine effector genes that lack homologs among the sequenced T1-like strains. Of these, hopNl was selected as a candidate diagnostic locus for the Pto DC3000/P. syringae pv. maculicola subgroup. The hopN1 sequences in the Hop Database (www.pseudomonas-syringae.org) were aligned to identify conserved regions.

Primers derived from T3E genes avrA, hopW1, and hopN1 effectively discriminate among high and low virulence strains of $\boldsymbol{P}$. syringae pathogenic on tomato. To confirm the efficacy of the avrA and hopWl genes as diagnostic loci for strains in the T1like subgroup, four primer combinations derived from conserved regions in these genes were evaluated (Tables 4 and 5). Products of the expected size were amplified from $P$. syringae pv. tomato T1, NYS-T1, K40, NCPPB1108, Max13, and JL1065. No products were amplified from either $P$. syringae pv. tomato DC3000 or the

Table 5. PCR production amplification from primers developed in this study ${ }^{\mathrm{x}}$

\begin{tabular}{|c|c|c|c|c|c|c|c|c|c|c|c|c|c|c|c|c|c|}
\hline & \multirow[b]{2}{*}{ Primers } & \multicolumn{4}{|c|}{ avrA } & \multicolumn{4}{|c|}{ hopWI } & \multicolumn{4}{|c|}{ hopN1 } & \multicolumn{4}{|c|}{ hopRI } \\
\hline & & $\begin{array}{c}547 \mathrm{f} \\
1321 \mathrm{r}\end{array}$ & $\begin{array}{c}547 \mathrm{f} \\
1219 \mathrm{r}\end{array}$ & $\begin{array}{c}215 f \\
1321 r\end{array}$ & $\begin{array}{l}215 f \\
1219 r\end{array}$ & $\begin{array}{c}173 f \\
1099 r\end{array}$ & $\begin{array}{c}173 f \\
1327 r\end{array}$ & $\begin{array}{c}313 f \\
1099 r\end{array}$ & $\begin{array}{c}313 f \\
1327 r\end{array}$ & $\begin{array}{c}91 \mathrm{f} \\
771 \mathrm{r}\end{array}$ & $\begin{array}{c}91 f \\
816 r\end{array}$ & $\begin{array}{l}142 \mathrm{f} \\
771 \mathrm{r}\end{array}$ & $\begin{array}{l}142 \mathrm{f} \\
816 \mathrm{r}\end{array}$ & $\begin{array}{c}427 \mathrm{f} \\
1129 \mathrm{r}\end{array}$ & $\begin{array}{c}427 f \\
1299 r\end{array}$ & $\begin{array}{c}705 f \\
1129 r\end{array}$ & $\begin{array}{c}705 f \\
1299 r\end{array}$ \\
\hline $\begin{array}{l}\text { P. syringae pv. } \\
\text { tomato }\end{array}$ & Isolate & & & & & & & & & & & & & & & & \\
\hline T1 subgroup & $\mathrm{T} 1$ & + & + & + & + & + & + & + & + & - & - & - & - & + & + & + & + \\
\hline $\mathrm{T} 1$ subgroup & NYS-T1 & + & + & + & + & + & + & + & + & - & - & - & - & + & + & + & + \\
\hline $\mathrm{T} 1$ subgroup & $\operatorname{Max} 13$ & + & + & + & + & + & + & + & + & - & - & - & - & + & + & + & + \\
\hline $\mathrm{T} 1$ subgroup & NCPPB1108 & + & + & + & + & + & + & + & + & - & - & - & - & + & + & + & + \\
\hline $\mathrm{T} 1$ subgroup & $\mathrm{K} 40$ & + & + & + & + & + & + & + & + & - & - & - & - & + & + & + & + \\
\hline \multirow[t]{2}{*}{ T1 subgroup } & A9 & + & + & + & + & + & + & + & + & - & - & - & - & + & + & + & + \\
\hline & JL1065 & + & + & + & + & + & + & + & + & - & - & - & - & + & + & + & + \\
\hline $\begin{array}{l}\text { DC } 3000 / \\
\text { P. syringae pv. } \\
\text { maculicola } \\
\text { subgroup }\end{array}$ & DC3000 & - & - & - & - & - & - & - & - & + & + & + & + & + & + & + & + \\
\hline $\begin{array}{l}\text { DC } 3000 / \\
\text { P. syringae pv. } \\
\text { maculicola } \\
\text { subgroup }\end{array}$ & M3 & - & - & - & - & - & - & - & - & + & + & + & + & + & + & + & + \\
\hline $\begin{array}{l}\text { DC } 3000 / \\
P . \text { syringae } \mathrm{pv} . \\
\text { maculicola } \\
\text { subgroup }\end{array}$ & M6 & - & - & - & - & - & - & - & - & + & + & + & + & + & + & + & + \\
\hline unknown & 0578 & + & + & + & + & + & + & + & + & - & - & - & - & + & + & + & + \\
\hline unknown & 0761 & + & + & + & + & + & + & + & + & - & - & - & - & + & + & + & + \\
\hline unknown & 09084 & + & + & + & + & + & + & + & + & - & - & - & - & + & + & + & + \\
\hline unknown & 12042 & + & + & + & + & + & + & + & + & - & - & - & - & + & + & + & + \\
\hline unknown & 13093 & + & + & + & + & + & + & + & + & - & - & - & - & + & + & + & + \\
\hline unknown & 13110 & + & + & + & + & + & + & + & + & - & - & - & - & + & + & + & + \\
\hline $\begin{array}{l}\text { P. syringae } \mathrm{pv} . \\
\text { antirrhini }\end{array}$ & Pat126 & - & - & - & - & - & - & - & - & - & - & - & - & + & + & + & + \\
\hline $\begin{array}{l}\text { P. syringae pv. } \\
\text { syringae }\end{array}$ & B728a & - & - & - & - & - & - & - & - & - & - & - & - & - & - & - & - \\
\hline P. viridiflava & 10078 & - & - & - & - & - & - & - & - & - & - & - & - & - & - & - & - \\
\hline P. fulva & 0430 & - & - & - & - & - & - & - & - & - & - & - & - & - & - & - & - \\
\hline P. fluorescens & 09110 & - & - & - & - & - & - & - & - & - & - & - & - & - & - & - & - \\
\hline P. putida & 09112 & - & - & - & - & - & - & - & - & - & - & - & - & - & - & - & - \\
\hline $\begin{array}{l}\text { Xanthomonas } \\
\text { perforans }\end{array}$ & 13091 & $+\mathrm{y}$ & $+\mathrm{y}$ & $++^{y}$ & $++^{\mathrm{y}}$ & $t^{\mathrm{z}}$ & - & - & - & - & - & - & - & - & - & $t^{\mathrm{z}}$ & $+^{\mathrm{z}}$ \\
\hline \multirow{4}{*}{$\begin{array}{l}\text { Clavibacter } \\
\text { michiganensis } \\
\text { subsp. } \\
\text { michiganensis }\end{array}$} & 13048 & - & - & - & - & - & - & - & - & - & - & - & - & - & - & - & - \\
\hline & 13085 & - & - & - & - & - & - & - & - & - & - & - & - & - & - & - & - \\
\hline & 13117 & - & - & - & - & - & - & - & - & - & - & - & - & - & - & - & - \\
\hline & 13129 & - & - & - & - & - & - & - & - & - & - & - & - & - & - & - & - \\
\hline
\end{tabular}

\footnotetext{
$\mathrm{x}+$ Target amplification with corresponding primer pair and isolate; - no amplification with corresponding primer pair and isolate.

y Weak target amplification at lower annealing temperatures.

${ }^{\mathrm{z}}$ Weak target amplification at all annealing temperatures.
} 
P. syringae pv. maculicola strains M3 or M6 (Table 5, Fig. 2). The primers $215 \mathrm{f}$ and $1321 \mathrm{r}$ for $a v r A$ were selected for diagnostics to distinguish T1-like strains from the DC3000/P. syringae pv. maculicola strains using an annealing temperature of $65^{\circ} \mathrm{C}$.

Two primer combinations aligning to conserved regions of hopN1 were evaluated with members of the T1-like and DC3000/ $P$. syringae pv. maculicola subgroups. Amplified products of the expected size were apparent for DC3000, $P$. syringae pv. maculicola M3 and M6, but not for any of the T1-like strains, confirming the utility of this locus for distinguishing the DC3000/P. syringae pv. maculicola subgroup (Table 5).

The T3E gene hopRl is highly conserved among Group I $P$. syringae strains associated with tomato and was used for development of primers that can generally distinguish these strains from other $P$. syringae groups. As shown in Table 5, all $P$. syringae isolates tested yielded an amplified product with the exception of $P$. syringae pv. syringae $\mathrm{B} 728 \mathrm{a}$, which is a member of $P$. syringae Group II.
None of the non- $P$. syringae bacterial pathogens evaluated yielded a hopRl amplification product (Table 5, Fig. 2).

Primer sets were used to evaluate the subgroup membership of six $P$. syringae isolates from the Smart lab collection. All showed amplification products using all the $a v r A$ and $h o p R$ primer combinations and no products from hopN primers, confirming membership of these strains in the T1-like subgroup.

Amplification patterns resulting from a multiplex PCR employing avrA primers $215 \mathrm{f}$ and $1321 \mathrm{r}$ and hopRl primers $427 \mathrm{f}$ and $1129 \mathrm{f}$ are shown in Figure 2. Results show target-sized amplification products for the avrA primer set for strains in the T1-like subgroup. Target amplification was seen for hopRl primers in both the T1-like and DC3000/P. syringae pv. maculicola strains. No amplification was observed for the remaining pseudomonads or other bacterial pathogens of tomato. The applicability of the multiplex PCR test for detection of high virulence T1-like in field isolates was demonstrated by use of these primers on infected

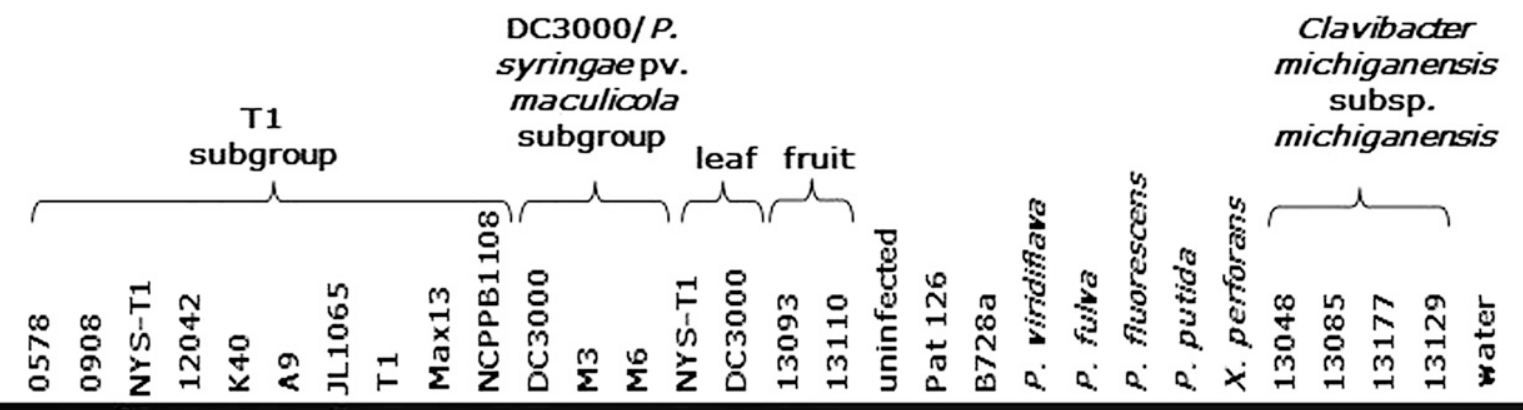

$M 123456789101112131415161718192021222324252627282930 M$
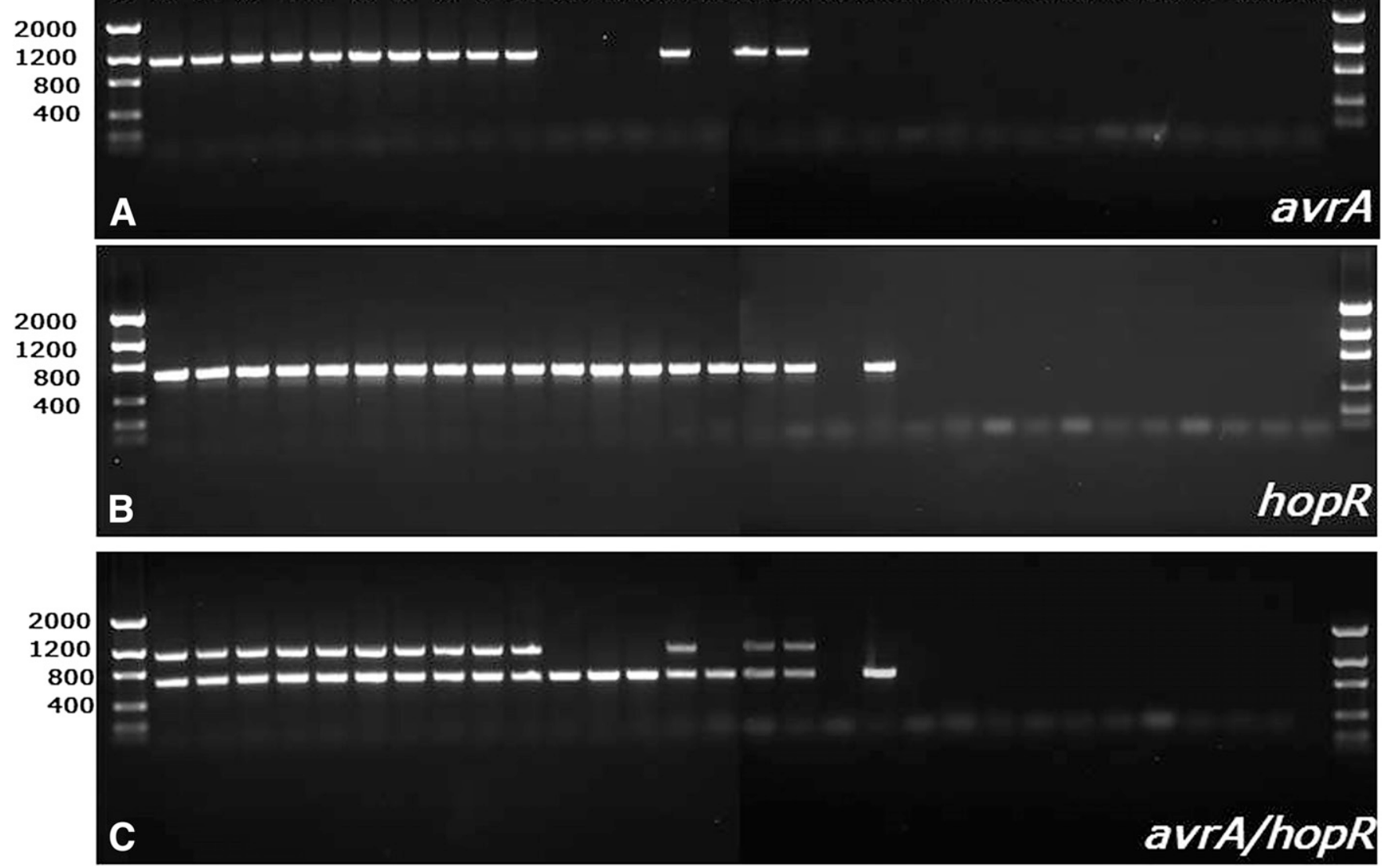

Fig. 2. Results of PCR amplification for T3Es. A, avrA primers $215 f$ and 1321 ; B, hopR1 primers $427 f$ and $1129 \mathrm{r}$; and C, multiplex with avrA primers $215 f$ and $1321 \mathrm{r}$ and hopR1 primers $427 f$ and 1129r. Lanes are as follows: M: DNA ladder (Invitrogen, Low DNA Mass Ladder); (1-11 P. syringae pv. tomato) 1: 0578; 2: 09084; 3: NYS-T1; 4: 12042; 5: K40; 6: A9; 7: JL1065; 8: T1; 9: Max13; 10: NCPPB1108; 11: DC3000; (12 and 13 P. syringae pv. maculicola) 12: M3; 13: M6; 14: leaf tissue infected with NYS-T1; 15: leaf tissue infected with DC3000; 16: fruit tissue infected with 13093; 17: fruit tissue infected with 13110; 18: healthy tomato leaf tissue; 19: P. syringae pv. antirrhini Pat126; 20: P. syringae pv. syringae B728a; 21: P. viridiflava 10078; 22: P. fulva 0430; 23: P. fluorescens 09110; 24: P. putida 09112; 25: X. perforans 13091; (26-29 C. michiganensis subsp. michiganensis strains) 26: 13048; 27: 13085; 28: 13177; 29: 13129; 30: negative water control. 
tomato leaf and fruit tissue. An annealing temperature of $65^{\circ} \mathrm{C}$ is recommended given that weak amplification was observed at lower temperatures in $X$. perforans for some of the primer combinations (Table 5).

Comparative virulence of pseudomonads on tomato. The average number of necrotic specks per tomato leaflet was highest among the T1-like $P$. syringae pv. tomato strains NYS-T1, K40, 09084, A9, and T1 (Table 6). P. syringae pv. tomato DC3000 and P. viridiflava 10078 showed average specks per leaflet counts that were not significantly different from the water control at the inoculation level used in these assays (Table 6). The average specks per leaflet for DC3000 was lower than that of those for the T1-like strains, but statistically significant differences were not found between DC3000 and the T1-like strains T1 and A9.

\section{Discussion}

Plant pathogen populations are dynamic in structure and distribution, responding to a broad array of variables including the genetic makeup and spatial distribution of the host as well as agronomic practices contributing to spread of infected material. Among Group I $P$. syringae isolates, the more recently evolved T1-like subgroup has become predominant over less virulent, broader hostrange strains in the DC3000/P. syringae pv. maculicola subgroup (10). Continued monitoring of changes in lineage distribution and evolution can benefit from development of reliable and discriminating DNA-based diagnostic assays that, unlike culture-based methods, are capable of detecting differences among phenotypically distinct sublineages. To date, most DNA-based detection of $P$. syringae has relied on primers hybridizing to genes widely conserved among diverse isolates, or against biosynthetic genes for the phytotoxin coronatine, which are unevenly distributed among $P$. syringae pv. tomato strains and not consistently correlated with virulence.

The appearance of a highly virulent strain of $P$. syringae pv. tomato in a New York state tomato field in 2009 reinforced the need for diagnostic tools for use in quickly discerning the lineage of $P$. syringae strains. To assess the relationship of the new isolate to previously sequenced strains, a draft genome sequences was generated. MLST analysis placed the new isolate in the T1-like subgroup of $P$. syringae pv. tomato.

$P$. syringae virulence is determined by a combination of genetic factors including phytotoxins, T3Es, and the extent to which conserved pattern associated molecular patterns (PAMPS) are detected by host receptors. $P$. syringae T3Es act chiefly by suppressing host immune responses, and are regulated by the HrpL alternative sigma factor $(7,32)$, bioinformatic prediction of which is an efficient strategy for locating T3E genes and other members of the HrpL regulon.

The best characterized representatives of the T1-like and DC3000/ $P$. syringae pv. maculicola subgroups are T1 and DC 3000 . The T3E repertoires of these two strains differ significantly, with only $14 \mathrm{~T} 3 \mathrm{E}$ genes shared between them and 15 and 11 unique to DC3000 and T1, respectively (2). The repertoire of previously confirmed T3Es and

Table 6. Average specks per leaflet on tomatoes inoculated with pseudomonads $^{\mathrm{z}}$

\begin{tabular}{lcl}
\hline Isolate & $\begin{array}{c}\text { Average specks } \\
\text { per leaflet (SE) }\end{array}$ & \\
\hline Pseudomonas syringae pv. tomato NYS-T1 & $7.16(1.48)$ & $\mathrm{a}$ \\
P. syringae pv. tomato K40 & $6.76(1.02)$ & $\mathrm{a}$ \\
P. syringae pv. tomato 09084 & $5.85(0.67)$ & $\mathrm{a}$ \\
P. syringae pv. tomato A9 & $4.76(0.44)$ & $\mathrm{ab}$ \\
P. syringae pv. tomato T1 & $4.71(0.55)$ & $\mathrm{ab}$ \\
P. syringae pv. tomato DC3000 & $1.61(0.13)$ & $\mathrm{bc}$ \\
P. viridiflava 10078 & $0.16(0.54)$ & $\mathrm{c}$ \\
Water & $0(0)$ & $\mathrm{c}$ \\
\hline
\end{tabular}

${ }^{\mathrm{z}}$ Different letters represent significantly different groups. Numbers reflect average value of two biological repetitions using data 12 days postinoculation.
non-T3E members of the HrpL regulon in NYS-T1 were identified by sequence similarity and HrpL binding site prediction, and were found to be identical to those in T1. NYS-T1 was found to encode a predicted protein with limited similarity to the T3E HopAO1 and downstream of a HrpL binding site. This gene is absent from T1 and DC3000 but its potential role in NYS-T1 virulence remains to be evaluated.

Of the observed differences in predicted virulence factors, the presence of coronatine in NYS-T1 is most significant. Coronatine has been shown to enhance fitness of $P$. syringae pathovars by facilitating entry into plants through stomata and promoting growth in planta (43), and is typically identifiable by the presence of yellowish halos around the speck lesions. Many $P$. syringae pathovars produce coronatine, but the presence of coronatine biosynthetic genes is not closely correlated with strain phylogeny or host range among and within pathovars (5).

The sequence difference in the flgII-28 epitope of the flagellin structural protein (FliC) is also significant given the importance of PAMP-triggered immunity in host defense (9) wherein the host plant recognizes molecular patterns in highly conserved gene products. Cai et al. demonstrated that the flgII- 28 sequence in strain Max 13 triggers a weaker defense response than the flgII-28 sequence of strains DC3000 or T1 (10). Comparison of FliC sequences among the strains reveals that NYS-T1 encodes the sequence variant present in Max13, potentially contributing to the high virulence of NYS-T1 by reducing the host defense response.

Comparative virulence analyses of $P$. syringae strains in the T1-like and DC3000/P. syringae pv. maculicola subgroups have consistently shown the former to be the more virulent on tomato. To develop a diagnostic test capable of distinguishing these two subgroups, genome sequences of high virulence T1-like strains were compared with the DC3000 sequence and a core set of confirmed T3Es in the T1-like subgroup identified. Primers were developed from conserved sequences in the subgroup-specific effectors and shown to be effective in discriminating among isolates. Specifically, primers designed against conserved regions in avrA and hopWl proved diagnostic for the T1-like subgroup and primers against hopN1 for the DC3000/P. syringae pv. maculicola subgroup, with hopRI discriminating Group I $P$. syringae strains from other phylogenetic $P$. syringae groups as well as other bacteria associated with tomato. Using this protocol, six previously uncharacterized $P$. syringae isolates from the Smart lab were shown to be members of the T1-like subgroup (Table 5, Fig. 2).

The extent of host plant damage in the field of isolation suggested that NYS-T1 exhibited virulence levels equal to or greater than other T1-like strains. Consistent with previous reports (10,31), T1-like strains were the most virulent. Strain T1 itself caused numerically fewer specks per leaflet than other strains in the subgroup, possibly reflecting the absence of coronatine production; however, this difference was not statistically significant (Table 6).

Why the T1-like subgroup exhibits higher levels of virulence on tomato than the DC3000/P. syringae pv. maculicola strains remains unclear, though differences in the T3E repertoires are suggestive of different "strategies" for pathogenesis. One possibility is that the composition and large number of T3Es encoded by strain DC3000 is necessary for a host range that includes both tomato and brassica species, while the particular complement of T3Es conserved in the T1-like subgroup achieves greater virulence on tomato only. In contrast, neither the genes for coronatine biosynthesis nor the fliC allele associated with evasion of innate immunity are strongly associated with subgroup or host range.

\section{Acknowledgments}

This study was funded by the National Research Initiative Competitive Grants Program Grant number 2009-55605-05184 from the National Institute of Food and Agriculture, a grant from the National Science Foundation's Plant Genome Research Program award number NSF-PGRP IOS-1025642, and the Andrew J. and Grace B. Nichols endowment to A.C.

We would like to thank Holly Lange and Carol Bowden for their support in the greenhouse. 


\section{Literature Cited}

1. Almeida, N. F., Yan, S., Cai, R., Clarke, C. R., Morris, C. E., Schaad, N. W., and Vinatzer, B. A. 2010. PAMDB, A multilocus sequence typing and analysis database and website for plant-associated microbes. Phytopathology 100:208-215.

2. Almeida, N. F., Yan, S., Lindeberg, M., Studholme, D. J., Schneider, D. J., Condon, B., Liu, H., Viana, C. J., Warren, A., Evans, C., Kemen, E., Maclean, D., Angot, A., Martin, G. B., Jones, J. D., Collmer, A., Setubal, J. C., and Vinatzer, B. A. 2009. A draft genome sequence of Pseudomonas syringae pv. tomato T1 reveals a type III effector repertoire significantly divergent from that of Pseudomonas syringae pv. tomato DC3000. Mol. Plant Microbe Interact. 22:52-62.

3. Aziz, R., Bartels, D., Best, A. A., DeJongh, M., Disz, T., Edwards, R. A., Formsma, K., Gerdes, S., Glass, E. M., Kubal, M., Meyer, F., Olsen, G. J., Olson, R., Osterman, A. L., Overbeek, R. A., McNeil, L. K., Paarmann, D., Paczian, T., Parrello, B., Pusch, G. D., Reich, C., Stevens, R., Vassieva, O., Vonstein, V., Wilke, A., and Zagnitko, O. 2008. The RAST Server: rapid annotations using subsystems technology. BMC Genomics 9:75-89.

4. Baltrus, D. A., Nishimura, M. T., Romanchuk, A., Chang, J. H., Mukhtar, M. S., Cherkis, K., Grant, S. R., Jones, C. D., Dangl, J. L., and Roach, J. 2011. Dynamic evolution of pathogenicity revealed by sequencing and comparative genomics of 19 Pseudomonas syringae isolates. PLoS Pathog. 7:e1002132.

5. Bereswill, S., Bugert, P., Völksch, B., Ullrich, M., Bender, C. L., and Geider, K. 1994. Identification and relatedness of coronatine-producing Pseudomonas syringae pathovars by PCR analysis and sequence determination of the amplification products. Appl. Environ. Microbiol. 60:2924-2930.

6. Bertani, G. 1951. Studies on lysogenesis. The mode of phage liberations by lysogenic Escherichia coli. J. Bact. 62:293-300.

7. Block, A., and Alfano, J. R. 2011. Plant targets for Pseudomonas syringae type III effectors: virulence targets or guarded decoys? Curr. Opin. Microbiol. 14:39-46.

8. Boetzer, M., Henkel, C. V., Jansen, H. J., Butler, D., and Pirovano, W. 2011. Scaffolding pre-assembled contigs using SSPACE. Bioinformatics 27:578-579.

9. Boller, T., and Felix, G. 2009. A renaissance of elicitors: perception of microbe-associated molecular patterns and danger signals by patternrecognition receptors. Annu. Rev. Plant Biol. 60:379-406.

10. Cai, R., Yan, S., Liu, H., Leman, S., and Vinatzer, B. A. 2011. Reconstructing host range evolution of bacterial plant pathogens using Pseudomonas syringae pv. tomato and its close relatives as a model. Infection, genetics and evolution. Infect. Genet. Evol. 11:1738-1751.

11. Chen, W. P., and Kuo, T. T. 1993. A simple and rapid method for the preparation of gram-negative bacterial genomic DNA. Nucleic Acids Res. 21:2260.

12. Chevreux, B., Pfisterer, T., Drescher, B., Driesel, A. J., Müller, W. E., Wetter, T., and Suhai, S. 2004. Using the miraEST assembler for reliable and automated mRNA transcript assembly and SNP detection in sequenced ESTs. Genome Res. 14:1147-1159.

13. Chun, W. C. C. 1982. Identification and detection of Corynebacterium michiganense in tomato seed using the indirect enzyme-linked immunosorbent assay. MSc. University of Hawaii, Honolulu, HI.

14. Collmer, A., Lindeberg, M., Petnicki-Ocwieja, T., Schneider, D. J., and Alfano, J. R. 2002. Genomic mining type III secretion system effectors in Pseudomonas syringae yields new picks f. or all TTSS prospectors. Trends Microbiol. 10:462-469.

15. Cuppels, D. A., and Ainsworth, T. 1995. Molecular and physiological characterization of Pseudomonas syringae pv. tomato and Pseudomonas syringae pv. maculicola strains that produce the phytotoxin coronatine. Appl. Environ. Microbiol. 61:3530-3536.

16. Cuppels, D. A., Louws, F. J., and Ainsworth, T. 2006. Development and evaluation of PCR-based diagnostic assays for the bacterial speck and bacterial spot pathogens of tomato. Plant Dis. 90:451-458.

17. Darling, A., Mau, B., Blattner, F. R., and Perna, N. T. 2004. Mauve: multiple alignment of conserved genomic sequence with rearrangements. Genome Res. 14:1394-1403.

18. Debener, T., Lehnackers, H., Arnold, M., and Dangl, J. L. 1991. Identification and molecular mapping of a single Arabidopsis thaliana locus determining resistance to a phytopathogenic Pseudomonas syringae isolate. Plant J. 1:289-302.

19. European and Mediterranean Plant Protection Organization (EPPO). 2005. Clavibacter michiganensis subsp. michiganensis. EPPO Bull. 35:275-283 Paris, France.

20. Fanelli, V., Cariddi, C., and Finetti-Sialer, M. 2007. Selective detection of Pseudomonas syringae pv. tomato using dot blot hybridization and realtime PCR. Plant Pathol. 56:683-691.

21. Gropp, S. J., and Guttman, D. S. 2004. The PCR amplification and characterization of entire Pseudomonas syringae hrp/hrc clusters. Mol. Plant Pathol. 5:137-140.

22. Hendson, M., Hildebrand, D. C., and Schroth, M. N. 1992. Relatedness of Pseudomonas syringae pv. tomato, Pseudomonas syringae pv. maculicola and Pseudomonas syringae pv. antirrhini. J. Appl. Microbiol. 73:455-464.

23. Jones, J. B., and Jones, J. P. 1984. Pseudomonas viridiflava: causal agent of bacterial leaf blight of tomato. Plant Dis. 68:341-342.

24. Jones, J. B., Lacy, G. H., Bouzar, H., Stall, R. E., and Schaad, N. W. 2004. Reclassification of the xanthomonads associated with bacterial spot disease of tomato and pepper. Syst. Appl. Microbiol. 27:755-762.
25. Keb-Llanes, M., Gonzalez, G., Chi-Manzanero, B., and Infant, D. 2002 A rapid and simple method for small-scale DNA extraction in Agavaceae and other tropical plants. Plant Mol. Biol. Rep. 20:299a-299e.

26. Kelley, D., Schatz, M. C., and Salzberg, S. L. 2010. Quake: quality-aware detection and correction of sequencing errors. Genome Biol. 11:r116.

27. King, E. O., Ward, M. K., and Raney, D. E. 1954. Two simple media for the demonstration of pyocyanin and fluorescin. J. Lab. Clin. Med. 44:301-307.

28. Koike, S. T., Gladders, P., and Paulus, A. O. 2007. Vegetable diseases: a color handbook. Academic Press, Massachusetts.

29. Kozik, E. U. 2002. Studies on the resistance of bacterial speck (Pseudomonas syringae pv. tomato) in tomato cv. Ontario 7710. Plant Breed. 121:526-530.

30. Kozik, E. U., Putawska, J., and Sobiczewski, P. 2006. Genetic Similarity of Pseudomonas syringae pv. tomato strains showing various virulence. J. Plant Prot. Res. 46:325-333.

31. Kunkeaw, S., Tan, S., and Coaker, G. 2010. Molecular and evolutionary analyses of Pseudomonas syringae pv. tomato race 1 . Mol. Plant Microbe Interact. 23:415-424.

32. Lindeberg, M., Cunnac, S., and Collmer, A. 2012. Pseudomonas syringae type III effector repertoires: last words in endless arguments. Trends Microbiol. 20: 199-208.

33. Loper, J. E., and Lindow, S. E. 1987. Lack of evidence for in situ fluorescent pigment production by Pseudomonas syringae pv. syringae on bean leaf surfaces. Phytopathology 77:1449-1454.

34. Malathrakis, N. E., and Goumas, D. E. 1987. Bacterial soft rot of tomato in plastic greenhouses in Crete. Ann. Appl. Biol. 111:115-123.

35. McCarter, S. M., Jones, J. B., Gitaitis, R. D., and Smitley, D. R. 1983. Survival of Pseudomonas syringae pv. tomato in association with tomato seed, soil, host tissue, and epiphytic weed hosts in Georgia. Phytopathology 73: 1393-1398.

36. Nabizadeh-Ardekani, F., Koo, B., and Rudolph, K. 1997. The use of PCR to detect Pseudomonas syringae pv. tomato in planta. Pages 470-474 in: Developments in Plant Pathology: Pseudomonas syringae pathovars and related pathogens, vol. 9. K. Rudolph, T. J. Burr, J. W. Mansfield, D. Stead, A Vivian, and J. von Kietzell, eds. Kluwer Academic Publishers, the Netherlands.

37. Ronald, P. C., Salmeron, J. M., Carland, F. M., and Staskawicz, B. J. 1992. The cloned avirulence gene avrPto induces disease resistance in tomato cultivars containing the Pto resistance gene. J. Bacteriol. 174:1604-1611.

38. Saha, S., and Lindeberg, M. 2013. Bound to succeed: transcription factor binding-site prediction and its contribution to understanding virulence and environmental adaptation in bacterial plant pathogens. Mol. Plant Microbe Interact. 26:1123-1130.

39. Saitou, N., and Nei, M. 1987. The neighbor-joining method: A new method for reconstructing phylogenetic trees. Mol. Biol. Evol. 4:406-425.

40. Sarkar, S., and Guttman, D. S. 2004. Evolution of the core genome of Pseudomonas syringae, a highly clonal, endemic plant pathogen. Appl. Environ. Microbiol. 70:1999-2012.

41. Tamura, K., Nei, M., and Kumar, S. 2004. Prospects for inferring very large phylogenies by using the neighbor-joining method. Proc. Natl. Acad. Sci. USA 101:11030-11035.

42. Tamura, K., Stecher, G., Peterson, D., Filipski, A., and Kumar, S. 2013 MEGA6: Molecular evolutionary genetics analysis version 6.0. Mol. Biol. Evol. 30:2725-2729.

43. Uppalapati, S. R., Ishiga, Y., Wangdi, T., Kunkel, B. N., Anand, A., Mysore, K. S., and Bender, C. L. 2007. The phytotoxin coronatine contributes to pathogen fitness and is required for suppression of salicylic acid accumulation in tomato inoculated with Pseudomonas syringae pv. tomato DC3000. Mol. Plant Microbe Interact. 20:955-965.

44. Whalen, M. C., Innes, R. W., Bent, A. F., and Staskawicz, B. J. 1991. Identification of Pseudomonas syringae pathogens of Arabidopsis and a bacterial locus determining avirulence on both Arabidopsis and soybean. Plant Cell 3:49-59.

45. Wiebe, W. L., and Campbell, R. N. 1993. Characterization of Pseudomonas syringae pv. maculicola and comparison with P. s. tomato. Plant Dis. 77: 414-419.

46. Wilson, E. E., Zeitoun, F. M., and Fredickson, D. L. 1967. Bacterial phloem canker, a new disease of Persian walnut trees. Phytopathology 57:618-621.

47. Yan, S., Liu, H., Mohr, T. J., Jenrette, J., Chiodini, R., Zaccardelli, M., Setubal, J. C., and Vinatzer, B. A. 2008. Role of recombination in the evolution of the model plant pathogen Pseudomonas syringae pv. tomato DC3000, a very atypical tomato strain. Appl. Environ. Microbiol. 74: 3171-3181.

48. Yunis, H., Bashan, Y., Okon, Y., and Henis, Y. $+\leqslant \Delta \neq$. Weather dependence, yield losses, and control of bacterial speck of tomato caused by Pseudomonas tomato. Plant Dis. 64:937-939.

49. Zaccardelli, M., Spasiano, A., Bazzi, C., and Merighi, M. 2005. Identification and in planta detection of Pseudomonas syringae pv. tomato using PCR amplification of hrpZ Pst. Eur. J. Plant Pathol. 111:85-90.

50. Zerbino, D., and Birney, E. 2008. Velvet: algorithms for de novo short read assembly using de Bruijn graphs. Genome Res. 18:821-829. 